UDC 37:355.23:378.146

DOI https://doi.org/10.24919/2308-4863/44-1-38

\author{
Vladimir VOLOSHIN, \\ orcid.org 0000-0002-4809-0418 \\ Candidate of Pedagogical Sciences, Associate Professor, \\ Associate Professor at the Department of Physical Training and Personal Safety \\ National Academy of the State Border Guard Service of Ukraine \\ (Khmelnytsky, Ukraine) voloddm777@gmail.com
}

Eugene HOTIN, orcid.org 0000-0002-7564-2572

Teacher at the Department of Physical Training and Personal safety National Academy of the State Border Guard Service of Ukraine (Khmelnytsky, Ukraine) ehotin8@gmail.com

\title{
ENSURING THE DEVELOPMENT OF PHYSICAL PREPAREDNESS OF FUTURE BORDER OFFICERS IN A HIGHER MILITARY EDUCATIONAL INSTITUTION
}

The article presents a generalized analysis of the experience of providing physical training for future border service officers at the National Academy of the State Border Guard Service of Ukraine. The content (well-thought-out educational process, which includes education and training, and at the same time improving the physical fitness of border cadets, as well as their professional and functional readiness for professional activity), purpose (achieving physical improvement, mastering knowledge and developing skills) on the system of movements in a particular sport, achieving optimal sports results) and tasks (development of new ways and means of organizing educational activities in National Academy of the State Border Guard Service of Ukraine on the formation of the development of physical fitness of future border guards) physical training of future border officers. The problems of such training are identified taking into account modern challenges and requirements: implementation of the national security strategy, protection of the rights and freedoms of citizens, ensuring democratization in the field of security and defence, etc. The tasks that need to be solved in order to increase the level of physical fitness of future border guards are identified: the impact on strengthening their health, improving the professional applied training of border guards, mastering the skills of independent use of physical culture and sports in professional activities and daily life. Conclusions and directions of further research are formulated (analysis of the experience of physical training of security and defence specialists of the world's leading countries, study of NATO standards related to human resources in order to ensure the state European integration course, etc.).

Key words: future border officers, professional training, physical fitness, physical education, professional activity.

Володимир ВОЛОШИН,

orcid.org 0000-0002-4809-0418

кандидат педагогічних наук, доцент,

доиент кафедри фізичної підготовки та особистої безпеки

Національної академії Державної прикордонної служби України

(Хмельницький, Україна) voloddm777@gmail.com

Евгеній ХОТІНЬ,

orcid.org 0000-0002-7564-2572

викладач кафедри фізичної підготовки та особистої безпеки

Начіональної академії Державної прикордонної служби України

(Хмельнищький, Україна) ehotin8@gmail.com

\section{ЗАБЕЗПЕЧЕННЯ РОЗВИТКУ ФІЗИЧНОЇ ПІДГОТОВЛЕНОСТІ МАЙБУТНІХ ПРИКОРДОННИКІВ У ВИЩОМУ ВІЙСЬКОВОМУ НАВЧАЛЬНОМУ ЗАКЛАДІ}

У статті представлений узагальнений аналіз досвіду забезпечення фізичної підготовки майбутніх офіцерів прикордонної служби у Наиіональній академії Державної прикордонної служби України. Проаналізовано зміст (продуманий освітній прочес, в якому є і виховання $і$ навчання, $і$ водночас удосконалення фізичної підготовленості курсантів-прикордонників, а також їхньої професійно-функиіональної готовності до здійснення професійноі діяльності), мету (досягнення фізичного удосконалення, оволодіння знаннями та сформування умінь та навичок щодо системи рухів у певному виді спорту, досягненні оптимальних спортивних результатів) та завдання 
(розроблення нових шляхів та прийомів організаиії освітньої діяльності у НАДПСУ щодо формування розвитку фізичної підготовленості майбутніх офіцерів прикордонної служби) фізичної підготовки майбутніх офічерівприкордонників. Визначено проблеми такої підготовки з урахуванням сучасних викликів та вимог: реалізації національної безпекової стратегії, захисту прав та свобод громадян, забезпечення демократизаиії у сфері безпеки та оборони тощо. Визначено ті завдання, які необхідно вирішити задля підвищення рівня фізичної підготовленості майбутніх офіщерів-прикордонників: вплив на зміцнення їхнього здоров'я, на удосконалення професійної прикладної підготовленості курсантів-прикордонників, оволодіння навичками самостійного використання засобів фізичної культури та спорту у професійній діяльності та повсякденному житті. Сформульовано висновки та напрями подальших наукових досліджень (аналіз досвіду реалізаиії фізичної підготовки фахівиів сектору безпеки та оборони провідних країн світу, вивчення стандартів НАТО, щзо дотичні до людських ресурсів з метою забезпечення державного євроінтеграчійного курсу та ін.).

Ключові слова: майбутні офічери-прикордонники, професійна підготовка, фізична підготовленість, фізичне виховання, професійна діяльність.

Formulation of the problem. Modern society at the stage of development and dominance of information technology, the regularity of which has increased significantly, re-evaluates physical activity in their lives. The inability of scientific advances to replace mobility, dynamism and guarantee the health of citizens, even for high-level countries, has led to a new phase of interest in sports and physical education. The modern people, for whom there are many opportunities to build a career, achieve professional success, move to any part of the world, is experiencing a cognitive revolution. According to its results, a new system of values is built in a person's consciousness, and priorities are built in it.

Ukraine, which is in a state of transition in the development of its social spheres and institutions, is trying to ensure the optimal level of physical training of its citizens through the educational environment. The state of such training in military and law enforcement units deserves special attention.

The current content of the training of future border officers is multicomponent, as it provides for the presence of moral and psychological training, fire, personal safety, sports (physical education), militaryapplied, legal and humanitarian. All these components have their meaning. The content of physical training of future border officers is characterized by progressive principles of training, a wide range of interdependent professional and personal tasks, scientific feasibility of selection of tools and techniques, methods and technologies of this training, strategic long-term planning, high level of monitoring and control, standards and standards, etc.

Physical training of future border guards can be defined as a well-thought-out educational process, which includes education and training, and at the same time improving the physical fitness of border cadets, as well as their professional and functional readiness for professional activity.

The purpose of physical training (physical education) of future border guards is to achieve physical improvement, mastery of knowledge and skills in the system of movements in a particular sport, achieving optimal sports results.

Analysis of recent research and publications. The problem of physical training of future specialists in the security and defence sector is the subject of numerous pedagogical, psychological and sociological studies. The works of such scientists as: R. Anatsky (2010), E. Anokhin (2005), Y. Borodin (2008), A. Bosenko (2012), O. Boyarchuk (2010), Y. Verenga deserve special attention in the proposed problem (Verenga, 2014), V. Volkov (2011), O. Gnidyuk (2015), A. Oderov (2016), O. Petrachkov (2007), A. Petruk (2017), S. Romanchuk (2013), O. Semenov (2014).

The purpose of the article. The purpose of the presented publication is to generalize the experience of organizing physical training of future border guards, to study the problem of assessing their physical fitness.

Presenting main material. The successful functioning of modern society depends on the effective functioning of its fundamental institutions: legal, economic, political, cultural, and so on. A special status among all existing public institutions is given to law enforcement and the military. For the law enforcement public sphere, it is envisaged to perform functions related to the implementation of the national security strategy, protection of the rights and freedoms of citizens, ensuring democratization in the field of security and defence, etc. The content of these functions belongs to the needs of security of existence of each individual, which are a priority for the whole society. In view of this, it can be stated that the people who are entrusted with the performance of these functions need meaningful and in-depth training. In Ukrainian society there is a special law enforcement body - the State Border Guard Service of Ukraine (hereinafter - SBGS). The results of the professional activity of the said law enforcement body, which operates in the system of the Ministry of Internal Affairs of Ukraine, depend on the physical fitness of the representatives of the institution. 
Training of future officers of the SBGS is carried out at the National Academy of the State Border Guard Service of Ukraine (hereinafter - NASBGS), which has formed a high-level methodological system, cooperates experienced research and teaching staff, introduces innovations in educational activities, and special attention is paid to physical training of future officers, border guards.

Modern military affairs require the development of a high level of physical training and training of future border officers. Accelerated rates of technical reequipment form the need for a border guard professionals, who are able to master military-border equipment in the style of time and use it effectively in operational and service activities. Given this, the role of physical fitness of future border guards is growing.

The current conditions of operational and daily activities of the border service are associated with large amounts of physical and psycho-emotional stress. Accordingly, special attention needs to be paid to the organization of physical training of future border guards, development of new ways and methods of organizing educational activities in NASBGS on the formation of the development of physical fitness of future border guards.

Effective educational activities of future border guards to some extent depend on the level of their endurance, flexibility, coordination, strength and other important physical qualities (Verenga, 2014).

It is a well-known fact that there is an interdependence between the level of efficiency, productivity and rapid fatigue. Modern educational activities are characterized by hypodynamics, limited movements, static postures, which causes errors and inaccuracies in learning, has negative consequences for vital body systems (Gnydyuk, 2015).

The main solution to this problem in the educational activities of future border guards is to prevent such conditions. It is physical education classes that should help increase the productivity of border guards. The purpose of any physical education class is to form in future border guard's officer's interests and habits to perform physical exercises not only in the educational process, but also in everyday life. This situation indicates the importance of physical education classes, the impact of which should be increased and improved in the modern period. Qualitative training in physical education has a direct and indirect impact on the physical development of future officers of the border department. It should be noted that another confirmation of the importance of physical fitness of border cadets is the presence of the final exam in physical education.

In view of the above, the representatives of the scientific and pedagogical staff of the NASBGS, and in particular the Department of Physical Training and Personal Safety, are faced with the task of objectively assessing the physical fitness of future border officers. It is important to emphasize that the NASBGS assesses both theoretical and practical physical fitness of border cadets.

We studied the dynamics of the level of physical fitness of future border guards in NASBGS, which showed the following results: the system of physical training has a number of shortcomings, and therefore indicators of physical fitness during training change in the direction of decrease in the last year. The same standards operate for cadets of 3rd and 4th courses. Therefore, in the fourth year of study, only the maintenance of the level of physical fitness can be observed.

Representatives of the scientific and pedagogical staff of the Department of Physical Training and Personal Safety are searching for innovative organizational forms of educational activities in physical education at NASBGS to ensure normalization of motor activity of border cadets, health promotion and resistance to negative factors of professional activity. All these areas include: updating the work programs of the disciplines of the Department of Physical Training and Personal Safety, to implement the concept of cadet-cantered training, the inclusion of elements of operational and service activities of border guards in the training system of border cadets. Another important component of physical training of future border officers is to form the readiness of cadets to manage and organize physical training in the state border guards. It can be argued that pedagogical technologies of teaching disciplines of the Department of Physical Training and Personal Safety should provide a comprehensive approach to the training of future border guards on the basis of modern scientific and technical innovations in the theory and methodology of physical education.

In general, it is common to distinguish between two levels of physical fitness (available and required). These roosters are in contradictory relationship. For example, the high level of requirements for the profession of border guards stimulates the development of the required level of physical training of future border officers. Physical fitness can be a condition for improving the professional skills of border guards.

In our opinion, in ensuring the development of physical fitness of future officers of the border department should pay attention to the formation and development of priority military-applied skills of border guards, their psychological and special properties. With this in mind, the scientific and pedagogical staff of the NASBGS should determine 
special tasks for the physical training of future border guards, which will reflect the requirements for their professional activities and physical condition.

Conclusion. Thus, the NASBGS has formulated the most important task for physical education of future border guards, which will further have an impact on strengthening their health, improving the professional applied training of border cadets, mastering the skills of independent use of physical culture and sports in professional activities and everyday life. The low levels of physical fitness of future border guards are critical in Ukraine, but this is primarily due to the lack of attention to the problems of physical training at the family level, secondary school, etc.

In modern Ukrainian society, the psychophysical requirements for modern officers in military and law enforcement institutions are growing, which is manifested in the performance of their professional duties.

Promising areas of further research are the analysis of the experience of physical training of security and defence specialists of the world's leading countries, the study of NATO standards related to human resources in order to ensure the state's European integration course.

\section{BIBLIOGRAPHY}

1. Анацький Р. В. Удосконалення професійної підготовленості військовослужбовців внутрішніх військ МВС України засобами фізичної підготовки. Актуальні проблеми розвитку традииійних $і$ східних єдиноборств : зб. тез IV Міжнар. наук.-практ. інтернет-конф. (м. Харків, 12-14 квітня 2010 року). Харків : Акад. ВВ МВС України, 2010. C. 89-91.

2. Анохін С. Д. Фізична підготовка в арміях провідних країн НАТО : 401 навчально-методичний посібник. Львів : ЛВI, 2005. $115 \mathrm{c}$.

3. Бородін Ю. А., Пічугін М. Ф., Романчук В. М. Керівництво та організація фізичної підготовки у вищих військових навчальних закладах : навчальний посібник. Житомир : ЖВІ НАУ, 2008. 284 с.

4. Босенко А. І., Самокиш I. І., Трофименко І. Г. Оцінювання фізичної підготовленості студенток вищих навчальних закладів. Наука і освіта. 2012. № 4/CVV. С. 166-168.

5. Боярчук О. М. Фізична підготовка жіночого контингенту Збройних сил України в системі професійної діяльності : автореф. дис. ... канд. наук з фіз. виховання і спорту : 24.00.02. Львівський держ. ун-т фіз. культури. Львів, 2010.20 с.

6. Вереньга Ю. В. Зв'язок показників фізичної підготовленості та фізичного стану і здоров'я працівників MBC України на етапі професійного становлення. Науковий часопис Національного педагогічного університету імені М. П. Драгоманова. Серія № 15. Науково-педагогічні проблеми фізичної культури (фізична культура і спорт) : зб. наук. пр. 2014. Випуск 5(48) 14. С. 12-17.

7. Волков В. Л. Розвиток фізичних здібностей студентів у системі фізичної підготовки : монографія. Київ : Освіта України, 2011. 420 с.

8. Гнидюк О. П. Педагогічні умови підготовки майбутніх офіцерів-прикордонників до фізичного самовдосконалення : автореф. дис. ... канд. пед. наук : 13.00.04. Нац. академія Держ. прикордонної служби України імені Богдана Хмельницького. Хмельницький, 2015. 20 с.

9. Одеров А. М. Обгрунтування тесту фізичної підготовленості військовослужбовців : автореф. дис. ... канд. наук 3 фіз. виховання і спорту : 24.00.02. ДВНЗ «Прикарпатський нац. ун-т імені Василя Стефаника». Івано-Франківськ, 2016. $20 \mathrm{c}$.

10. Петрачков О. Аналіз взаємозв'язку між фізичною та професійною підготовленістю у військовослужбовців різних військових спеціальностей. Теорія і методика фіз. виховання і спорту. 2007. № 4. С. 67-69.

11. Петрук А. П. Оптимізація методичної складової системи фізичної підготовки курсантів вищих військових навчальних закладів : дис. ... канд. наук з фіз. виховання та спорту : 24.00.02. Нац. акад. сухопутних військ імені гетьмана Петра Сагайдачного. Львів, 2017. 259 с.

12. Романчук С. В. Теоретико-методологічні засади фізичної підготовки курсантів військових навчальних закладів Сухопутних військ Збройних сил України : дис. ... д-ра наук з фіз. виховання і спорту. 24.00.02 Нац. акад. сухопутних військ імені гетьмана Петра Сагайдачного. Львів, 2013. 540 с.

13. Семенова О. Є., Афонін В. М. Комплексний контроль фізичної підготовленості молоді у вищих навчальних закладах. Педагогіка, психологія та медико-біологічні проблеми фізичного виховання і спорту. 2010. № 12. С. 129 -131.

\section{REFERENCES}

1. Anatsky R. V. (2010). Udoskonalennya profesiynoyi pidhotovlenosti viys'kovosluzhbovtsiv vnutrishnikh viys'k MVS Ukrayiny zasobamy fizychnoyi pidhotovky [Improving the professional training of servicemen of the internal troops of the Ministry of Internal Affairs of Ukraine by means of physical training]. Actual problems of development of traditional and east martial arts: coll. thesis IV International scientific-practical Internet-conf. (Kharkiv, April 12-14, 2010). Kharkiv: Academia of the Ministry of Internal Affairs of Ukraine. P. 89-91 [in Ukrainian].

2. Anokhin E. D. (2005). Fizychna pidhotovka v armiyakh providnykh krayin NATO [Physical training in the armies of leading NATO countries]: 401 teaching method. manual. Lviv: LVI. 115 p. [in Ukrainian].

3. Borodin Y. A., Pichugin M. F., Romanchuk V. M. (2008). Kerivnytstvo ta orhanizatsiya fizychnoyi pidhotovky u vyshchykh viys'kovykh navchal'nykh zakladakh [Management and organization of physical training in higher military educational institutions]: textbook. Zhytomyr: ZhVI NAU. 284 p. [in Ukrainian]. 
4. Bosenko A. I., Samokish I. I., Trofimenko I. G. (2012). Otsinyuvannya fizychnoyi pidhotovlenosti studentok vyshchykh navchal'nykh zakladiv [Assessment of physical fitness of students of higher educational institutions]. Science and education. No. 4 / CVV. P. 166-168 [in Ukrainian].

5. Boyarchuk O. M. (2010). Fizychna pidhotovka zhinochoho kontynhentu Zbroynykh syl Ukrayiny v systemi profesiynoyi diyal'nosti [Physical training of the female contingent of the Armed Forces of Ukraine in the system of professional activity]: author's ref. Dissertation... Cand. Sciences in Phys. education and sports: 24.00.02. Lviv State University of Phys. culture. Lviv. 20 p. [in Ukrainian].

6. Verenga Y. V. (2014). Zv’yazok pokaznykiv fizychnoyi pidhotovlenosti ta fizychnoho stanu i zdorov'ya pratsivnykiv MVS Ukrayiny na etapi profesiynoho stanovlennya [The relationship between indicators of physical fitness and physical condition and health of employees of the Ministry of Internal Affairs of Ukraine at the stage of professional development]. Scientific journal Nat. ped. M. P. Drahomanov University. Series No. 15. Scientific and pedagogical problems of phys. culture (physical culture and sports): Coll. Science. pr. Issue 5 (48) 14. pp. 12-17 [in Ukrainian].

7. Volkov V. L. (2011). Rozvytok fizychnykh zdibnostey studentiv u systemi fizychnoyi pidhotovky [Development of physical abilities of students in the system of physical training]: monograph. Kyiv: Education of Ukraine. 420 p. [in Ukrainian].

8. Gnydyuk O. P. (2015). Pedahohichni umovy pidhotovky maybutnikh ofitseriv-prykordonnykiv do fizychnoho samovdoskonalennya [Pedagogical conditions of preparation of future border guards for physical self-improvement]: author's ref. Candidate of Dissertation ped. Science: 13.00.04. Nat. State Academy. Border Guard Service of Ukraine named after Bohdan Khmelnytsky. Khmelnytsky. 20 p. [in Ukrainian].

9. Oderov A. M.(2016). Obgruntuvannya testu fizychnoyi pidhotovlenosti viys'kovosluzhbovtsiv [Substantiation of the test of physical fitness of servicemen]: author's ref. Candidate of Dissertation Sciences in Phys. Education and Sports: 24.00.02. SHEI "Prykarpattia National Vasyl Stefanyk University". Ivano-Frankivsk. 20 p. [in Ukrainian].

10. Petrachkov O. (2007). Analiz vzayemozv'yazku mizh fizychnoyu ta profesiynoyu pidhotovlenistyu u viys'kovosluzhbovtsiv riznykh viys'kovykh spetsial'nostey [Analysis of the relationship between physical and professional training in servicemen of different military specialties]. Theory and methods of phys. education and sports. No. 4. P. 67-69 [in Ukrainian].

11. Petruk A. P. (2017). Optymizatsiya metodychnoyi skladovoyi systemy fizychnoyi pidhotovky kursantiv vyshchykh viys'kovykh navchal'nykh zakladiv [Optimization of the methodical component of the system of physical training of cadets of higher military educational institutions]: dissertation. Sciences in Phys. education and sports: 24.00.02. Nat. acad. ground troops named after Hetman Peter Sagaidachny. Lviv. 259 p. [in Ukrainian].

12. Romanchuk S. V. (2013). Teoretyko-metodolohichni zasady fizychnoyi pidhotovky kursantiv viys'kovykh navchal'nykh zakladiv Sukhoputnykh viys'k Zbroynykh syl Ukrayiny [Theoretical and methodological principles of physical training of cadets of military educational institutions of the Land Forces of the Armed Forces of Ukraine]: dissertation of Phys. education and sports: 24.00.02. Nat. acad. ground troops named after Hetman Peter Sagaidachny. Lviv. 540 p. [in Ukrainian].

13. Semenova O. E., Afonin V. M. (2010). Kompleksnyy kontrol' fizychnoyi pidhotovlenosti molodi u vyshchykh navchal'nykh zakladakh [Comprehensive control of physical fitness of youth in higher education]. Pedagogy, psychology and medical and biological problems of physical education and sports. No. 12. pp. 129-121 [in Ukrainian]. 